\title{
学会記事
}

\section{A Method for Building a Commonsense Inference Dataset based on Basic Events}

\author{
大村 和正 †
}

\section{まえがき}

本稿では，EMNLP2020に採択された表題の論文 “A Method for Building a Commonsense Inference Dataset based on Basic Events" (Omura, Kawahara, and Kurohashi) について解説す る。採択論文は, 拡張性・言語非依存性のある常識推論データセットの構築手法を提案したも のである。

\section{1 はじめに}

計算機による文章読解の実現は，自然言語処理の分野における大きな目標の一つである。こ の目標に向けて，計算機の文章読解能力を評価する問題設定を考え，そのデー夕を構築する研 究が盛んに行われている (Wang et al. 2019a, 2019b). 本研究も例外でなく，「文章読解に向け た言語資源を構築する」という目標を設定したところから始まった。

具体的な問題設定を決めるにあたり，（公財）日本漢字能力検定協会が提供している文章読 解・作成能力検定（文章検）の問題を参考に, 文章読解に必要な知識の分析と問題のデザイン の検討を行なった。この際に我々は，四級の文章検で出題される表 1 のような問題に目を付け た.この問題は次のような特徴があるために，自動生成を試みるにふさわしいと考えた．

（1）基本的なイベント間の蓋然的関係 1 を問い，解答に常識を必要とする.

(2) 問題のベースとなるイベントペアは, 談話標識を手掛かりにテキストから自動抽出できる. 一点目の特徵は, 計算機の常識推論能力の訓練／評価に利用できることを意味する。近年, 深層学習はめざましい発展を遂げている．特に大規模テキストで事前学習した汎用言語モデル BERT (Devlin et al. 2019) などにより，言い換え認識や構文解析など，基礎的な文章読解能力 を評価する夕スクでは人間に匹敵する精度が達成されている。しかし，これらの高性能なモデ ルでも，常識推論は依然として難しいことが示されている (Talmor et al. 2019). そのため, 計

\footnotetext{
†京都大学大学院情報学研究科

1 ある事柄がある程度起こりうる/真であるという関係。因果関係より広範な原因-結果の関係に着目するという意図 で，この用語を用いる。
} 
問 2 次の 1〜5 のそれぞれに、意味の上でも用法の上でも正しいものが続くように、最も適切なも のを、ア〜ウのうちから 1 つ選びなさい。

4 昨日はいつもに比べて宿題が多かったので、

ア 全て終わらせるのに夜までかかってしまった。

イ夕食後にゲームをする時間はないかもしれない。

ウテレビを見る時間をいつもより減らしたい。

表 1 四級の文章検で出題される問題例（実際の問題例より引用）。太字は正解選択肢である.

算機の常識推論能力を議論するために, 表 1 のような問題を作ることは意義があると考えた.

また, 二点目の特徵により，深層学習モデルの訓練データとして求められる規模のデータ構 築が可能である。ただし，テキストから自動抽出したイベントペアは (1) の性質を持つ（常識 的である）とは限らない。本研究では，基本的なイベント表現を含むことを条件付け，確認の ためのクラウドソーシングを組み达むことで，この問題に対処している.

以上が，本研究の着想に至る経緯である.

\section{2 提案手法}

\section{1 提案手法の鍵}

1 節で述べたように，テキストから抽出したイベントペアをベースに常識推論問題を作る場 合, そのイベントペアが常識的であることを保証する必要がある。そこで, 本研究では基本イ ベントと蓋然的基本イベントペアなるものを定義し，これらに着目する．基本イベントと蓋然 的基本イベントペアは以下のように定義される.

基本イベント テキストから抽出した述語項構造をクラスタリングし, その中の高頻度なもの を核とする表現

蓋然的基本イベントペア 蓋然的関係を持ち, 前件・後件が基本イベントであるイベントペア 提案手法の鍵は，ある蓋然的基本イベントペアをベースとし，その他のペアの後件を誤り選 択肢とすることで，常識推論問題を自動生成できるというものである（表 2). 蓋然的基本イベ ントペアは，基本イベントを核とし，クラウドワーカーによる確認を経るため，常識としての 知識の一般性をある程度保証している。また，問題は蓋然的基本イベントペアをもとに作られ るため, 常識推論能力を問うものになっている.

提案手法はテキストからの抽出をベースとするため, 拡張性があり, ドメインが限定される こともない. クラウドソーシングについても, 確認・フィルタリングを行なうだけなので, 低 コストかつ作文による annotation artifacts (Gururangan et al. 2018) の問題もない. また，人手 


\begin{tabular}{l|l}
\hline お腹が空いたので, ご飯を食べる & お腹が空いたので \\
ご飯を食べたら, すごく眠い & a. コーヒーを飲む \\
眠いので, コーヒーを飲む & b. ご飯を食べる \\
激しい運動をすると, 汗をかく & c. 汗をかく \\
\hline
\end{tabular}

表 2 蓋然的基本イベントペアの例（左）と，これらをもとにした常識推論問題の作問例（右）。太字は 正解選択肢である.

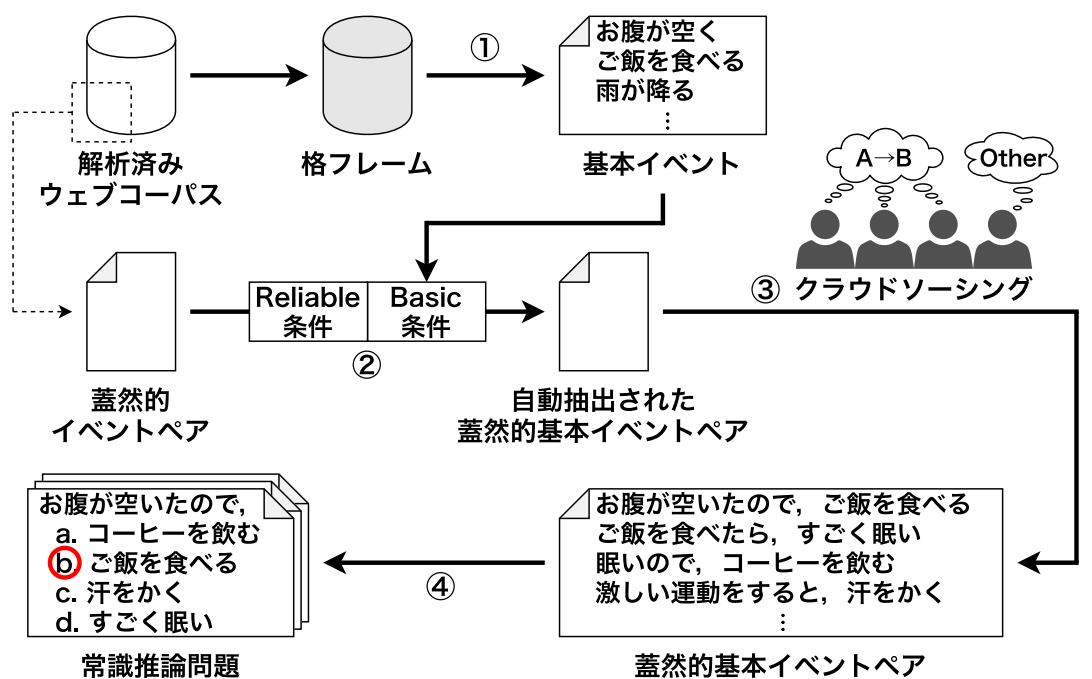

図 1 提案手法の概要図

で構築されたデータやクラウドソーシングに強く依存しないため, 談話標識を手掛かりにでき る言語においては同様の手法を適用することができる.

\section{2 提案手法の全体像}

提案手法は以下の 4 ステップから成る（図 1).

(1) 格フレーム 2 から高頻度な述語項構造を基本イベントとして獲得する。

（2）テキストに係り受け解析・談話関係解析を適用し，その結果，蓋然的関係を持つと認識 され，かつ基本イベントを核とするイベントペアを抽出する.

(3) 抽出したイベントペアが蓋然的関係を持つかどうかをクラウドソーシングで確認し, 蓋 然的基本イベントペアを得る.

\footnotetext{
2 本研究では, 京都大学格フレーム (https://www.gsk.or.jp/catalog/gsk2018-b) を利用した.
} 


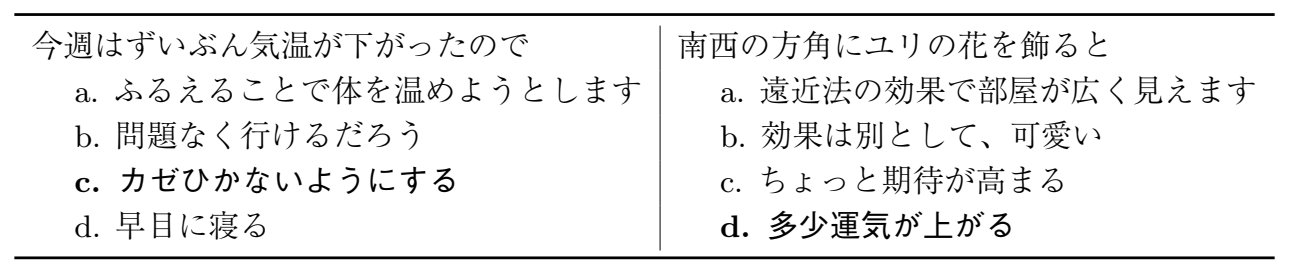

表 3 常識推論問題の生成例. 太字は正解選択肢である.

（4）蓋然的基本イベントペアから文脈と正解選択肢を作り，その他の中程度に類似するイベ ントペアの後件から誤り選択肢を選択することによって，常識推論問題を生成する. 各ステップの詳細については採択論文の $3 \cdot 4$ 章を参照されたい.

\section{3 提案手法の適用}

7.1 億文を含む日本語ウェブコーパスに提案手法を適用した結果，常識推論問題が 10.4 万問 生成された。表 3 に問題の生成例を示す。これらの常識推論問題について，計算機と人間によ

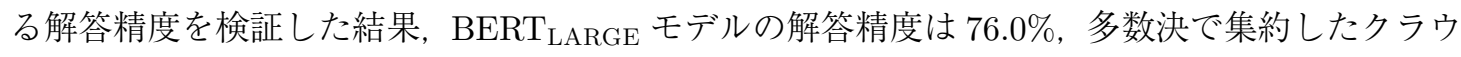
ドワーカーの解答精度は $88.9 \%$ であった（詳細は採択論文の $4 \cdot 5$ 章を参照）。常識推論能力に おいて，計算機と人間の間に開きがあることを示している.

\section{3 おわりに}

採択論文では，テキストからの自動抽出とクラウドソーシングを組み合わせた，拡張性・言 語非依存性のある常識推論データセットの構築手法を提案した，各問題は，基本的なイベント 間の蓋然的関係を問う多肢選択式問題である。提案手法を日本語ウェブコーパスに適用し，大 規模な常識推論データセットを構築した。計算機による解答実験の結果, 高性能な転移学習モ デルと人間の間に $10 \%$ 程度の開きがある, すなわち常識推論能力の評価に有効なデータセット であることを示した、構築したデータセットは, http://nlp.ist.i.kyoto-u.ac.jp/?KUCIに て公開している.

今後は, 構築したデータセットを利用して, 常識推論に向けたモデルやアルゴリズムの改善 に取り組む予定である。また, このデータセットで常識を学習し, 省略・照応解析や談話関係 解析など他の夕スクに応用することを検討する。

提案手法は，実際の検定問題から着想を得たこともあり，文章題の作問支援にも利用できる と考えられる。計算機だけでなく，人間の学習にも役立てられることを期待する。 


\section{参考文献}

Devlin, J., Chang, M.-W., Lee, K., and Toutanova, K. (2019). "BERT: Pre-training of Deep Bidirectional Transformers for Language Understanding." In Proceedings of the 2019 Conference of the North American Chapter of the Association for Computational Linguistics: Human Language Technologies, Volume 1 (Long and Short Papers), pp. 4171-4186.

Gururangan, S., Swayamdipta, S., Levy, O., Schwartz, R., Bowman, S., and Smith, N. A. (2018). "Annotation Artifacts in Natural Language Inference Data." In Proceedings of the 2018 Conference of the North American Chapter of the Association for Computational Linguistics: Human Language Technologies, Volume 2 (Short Papers), pp. 107-112.

Talmor, A., Herzig, J., Lourie, N., and Berant, J. (2019). "CommonsenseQA: A Question Answering Challenge Targeting Commonsense Knowledge." In Proceedings of the 2019 Conference of the North American Chapter of the Association for Computational Linguistics: Human Language Technologies, Volume 1 (Long and Short Papers), pp. 4149-4158.

Wang, A., Pruksachatkun, Y., Nangia, N., Singh, A., Michael, J., Hill, F., Levy, O., and Bowman, S. R. (2019a). "SuperGLUE: A Stickier Benchmark for General-Purpose Language Understanding Systems." In Advances in Neural Information Processing Systems 32, pp. 3266-3280.

Wang, A., Singh, A., Michael, J., Hill, F., Levy, O., and Bowman, S. R. (2019b). "GLUE: A Multi-Task Benchmark and Analysis Platform for Natural Language Understanding." In International Conference on Learning Representations.

\section{略歴}

大村 和正：2019 年京都大学工学部電気電子工学科卒業. 現在, 同大学大学院 情報学研究科修士課程に在籍中. 